\title{
Anatomic and functional outcome of eyes with massive submacular hemorrhage secondary to retinal macroaneurysm submitted to vitrectomy
}

\author{
Resultados anatômicos e funcionais em pacientes com \\ hemorragia submacular maciça secundária à macroaneurisma \\ arterial de retina submetidos à vitrectomia posterior
}

Leonardo Provetti Cunha ${ }^{1,2}$, Luciana Virgínia Ferreira Costa Cunha ${ }^{2}$, Carolina Ferreira Costa ${ }^{2}$, Hugo Henrique Moreira $^{3}$, Mário Luiz Ribeiro Monteiro ${ }^{4}$

\begin{abstract}
Purpose: To report the anatomic and functional outcome in patients with severe visual loss after acute massive submacular hemorrhage secondary to retinal arterial macroaneurysm submitted to vitrectomy and subretinal recombinant tissue plasminogen activator injection. Methods: Retrospective, observational, case-series of 4 eyes of 4 patients submitted to pars plana posterior vitrectomy (ppV) combined with internal limiting membrane (ILM) removal and subretinal recombinant tissue plasminogen activator (rtPA-12.5 mg/0.1 ml) injection with dilute $(20 \%)$ sulfur hexafluoride $\left(S F_{0}\right)$ gas in the vitreous cavity of eyes with recent onset $(\leq 7$ days) massive macular hemorrhage due to retinal arterial macroaneurysm (RAMA). Optical coherence tomography (OCT) was obtained both at presentation and during follow up. Results: Patients ranged in age from 63 to 78 years and all had systemic arterial hypertension. Visual acuity at presentation ranged from hand motions to count fingers at $50 \mathrm{~cm}$. All eyes showed extensive retinal hemorrhage involving more than two-thirds of macular area. The time between the onset of symptoms and the surgery ranged from 3 to 7 days. After a mean postoperative follow-up of $15.5 \pm 5.19$ months (range, 10-22 months), all eyes showed visual acuity improvement and final visual acuity ranged from 20/30 to 20/80. All had complete displacement of the subretinal hemorrhage from the fovea after the surgery. OCT images showed neurosensory retina thinning and disruption of the reflective line that represents the junction between inner and outer photoreceptors segments (IS/OS line) beneath the macular area and absence of the external limiting membrane (ELM). Conclusion: ppV associated with subretinal rtPA injection with intravitreal gas seems to be a safe and effective technique to promote visual improvement in patients with multilevel macular hemorrhage secondary to RAMA. Despite functional improvement, OCT images demonstrate that submacular hemorrhage leads to permanent structural damage to the neurosensory retina, especially to the outer photoreceptors layers.

Keywords: Eye hemorrhage; Retinal arterial/pathology; Aneurysm; Vitrectomy/methods; Tissue plasminogen activator; Macula lutea/pathology
\end{abstract}

\footnotetext{
${ }^{1,3}$ Universidade Federal de Juiz de Fora (MG), Brazil;

${ }^{2}$ Hospital de Olhos Juiz de Fora (MG), Brazil;

${ }^{4}$ Universidade de São Paulo (SP), Brazil.
}

This work was performed at Hospital de Olhos Juiz de Fora (MG), Brazil

The authors declare no conflicts of interest

Recebido para publicação em 19/11/2014 - Aceito para publicação em 12/2/2015 


\section{RESUMO}

Objetivo: Relatar os resultados anatômicos e funcionais em uma série de pacientes com perda visual grave por hemorragia submacular maciça aguda secundária a macroaneurisma arterial de retina (MAR) e descrever a técnica cirúrgica utilizada. Métodos: Este é um estudo retrospectivo, observacional, série de casos, incluindo 4 olhos de 4 pacientes que foram submetidos à cirurgia de vitrectomia posterior (VP), associada a peeling da membrane limitante interna (MLI) e injeção sub-retiniana de ativador do plasminogênio tecidual recombinante $(\mathrm{rtPA}-12,5 \mathrm{mg} / 0.1 \mathrm{ml})$ por hemorragia submacular maciça recente $(\leq 7$ dias) secundária MAR. Em todos os casos, o exame de tomografia de coerência óptica (OCT) foi obtido na consulta inicial e nas subsequentes para avaliação das alterações estruturais da retina. Resultados: A idade dos pacientes variou entre 63 a 78 anos e todos apresentavam hipertensão arterial sistêmica. A acuidade visual inicial nos olhos afetados variou de movimento de mãos a conta dedos a $50 \mathrm{~cm}$. Todos os olhos apresentaram hemorragia retiniana extensa ocupando mais do que dois terços da região macular. O tempo decorrido entre a perda visual e a cirurgia variou entre 3 a 7 dias. Após um seguimento médio de $15.5 \pm 5.19$ meses (variando entre 10 a 22 meses), a acuidade visual pós-operatória variou entre 20/30 e 20/80. Todos os olhos apresentaram um deslocamento completo da hemorragia subretiniana da região macular central no pós operatório. As imagens seccionais da retina obtidas pela OCT revelaram um afilamento da retina neurossensorial e interrupções na linha refletiva que representa a junção entre os segmentos internos e externos dos fotorreceptores na região macular, além de falhas na membrane limitante externa em todos os casos. Conclusão: De acordo com os resultados do presente estudo, a VP associada à injeção sub-retiniana de rtPA parece ser uma técnica segura e eficaz em promover melhora visual em pacientes com hemorragia submacular maciça secundária a MAR. Os achados do OCT revelaram que, apesar da grande melhora visual apresentada, a presença de hemorragia submacular pode promover danos estruturais permanentes da retina neurossensorial, em especial ao segmento externo dos fotorreceptores.

Descritores: Hemorragia ocular; Artéria retiniana/patologia; Aneurisma; Vitrectomia/métodos; Ativador de plasminogênio tecidual; Mácula lútea/patologia

\section{INTRODUCTION}

$\mathbf{S}$ ubmacular hemorrhage (SMH) is a potentially visual devasting condition. Its treatment is controversial and represents one of the most challenging topics in vitreoretinal surgery. SMH may result from multiple etiologies, including age-related macular degeneration (AMD), retinal arterial macroaneurysms (RAMA), polypoidal choroidal vasculopathy and trauma ${ }^{(1,2)}$.

RAMA are characterized by fusiform or round dilatations of a retinal arterioles on one of the four major branch retinal arteries, typically occurring within occurring within the third-order branches. They are commonly located at the site of an arteriovenous crossing or arteriolar bifurcations ${ }^{(3)}$, presumably secondary to focal arteriolar wall disease ${ }^{(4)}$. RAMA occur more frequently in women usually in sixth or seventh decade of life and are associated with systemic hypertension ${ }^{(3,5)}$. Although RAMA can be asymptomatic it may also cause sudden and severe visual loss as a result of massive retinal hemorrhage in macular area affecting multiple levels of the retina, including subinternal limiting membrane, intraretinal and subretinal spaces $^{(4)}$.

The natural history of SMH varies depending on the extension of hemorrhage. SMH secondary to RAMA usually portends a specially poor visual prognosis if left untreated ${ }^{(2)}$, due to several factors, including: direct toxic effects of iron and hemosiderin to the photoreceptors, metabolic impairment of photoreceptors, anatomic injury from clot contraction and submacular fibrotic scar formation ${ }^{(6,7)}$.

Treatment of SMH secondary to RAMA is controversial but most authors agree that early treatment, preferably within the first week, is a crucial factor for a favorable recovery in patients with massive bleeding ${ }^{(8)}$. There are a number of treatment strategies for $\mathrm{SMH}$, such as observation, laser photocoagulation, intravitreal gas injection, and pars plana vitrectomy with subretinal or intravitreal injection of recombinant tissue plasminogen activator (rtPA) but there are no formal guidelines regarding the optimal management ${ }^{(9,17)}$. According to some published serial cases, pars plana vitrectomy $(\mathrm{ppV})$ associated with subretinal rtPA injection seems to be a safe and effective technique in the management of acute massive $\mathrm{SMH}^{(18-20)}$.

Despite the visual improvement achieved in most patients with massive SMH secondary to RAMA who underwent $\mathrm{ppV}$ with subretinal rtPA injection, some of them may exhibit variable degrees of permanent visual loss, presumably related to structural macular changes ${ }^{(21)}$. Recent technological advances in optical coherence tomography (OCT) have allowed more detailed observation of ultra structural macular changes in many diseases. In a previous study, Tsujikawa et al. ${ }^{(21)}$ examined the OCT images of 44 eyes with exsudative or hemorrhagic complications of RAMA and investigated the association between retinal structural changes and visual prognosis. The authors demonstrated destruction of the foveal outer photoreceptor layer, resulting in poor visual outcome. Therefore, the ultra highresolution OCT can be a useful tool in detecting structural changes of the macula secondary to hemorragic complications of RAMA and provide a better understanding of the correlation between these structural changes and residual visual loss in such cases. The purpose of this study is to report the anatomic and functional outcomes in a series of patients with severe visual loss after acute massive submacular hemorrhage secondary to retinal arterial macroaneurysm and to describe the surgical technique.

\section{MethodS}

This is a retrospective, observational, case series of 4 eyes submitted to $\mathrm{ppV}$ combined with ILM removal and subretinal rtPAassisted pneumatic displacement for the treatment of recent $(\leq 7$ days) massive macular hemorrhage secondary to RAMA involving the center of the fovea. Only eyes with preretinal, subILM, and subretinal hemorrhage were included in the study. All patients underwent a complete ophthalmic examination, fluorescein angiography and OCT examination (Stratus OCT3000, Carl Zeiss, 
Dublin, CA; case 1 and 3D OCT-2000, Topcon, Tokyo, Japan; cases 2,3 and 4). Repeat ophthalmic examination and OCT were (also) obtained at each follow-up visit.

The diagnosis of retinal arterial macroaneurysm was based on fundus examination with the typical findings of hemorrhages in multiple levels, including preretinal, intraretinal, and subretinal involvement in macular area (figure 1). Fluorescein angiography showed hyperfluorescence corresponding to the active leakage of retinal macroaneurysm in one eye (case 3) and hypofluorescence secondary to blockage from the hemorrhage in the other 3 patients. OCT showed hyperreflection of the inner retina, which indicates preretinal and sub-ILM hemorrhage, and extensive subretinal blood.

All surgeries were performed by a single surgeon (LPC). All patients underwent three-port 25-gauge sutureless $\mathrm{ppV}$ and a posterior vitreous detachment was created if not already present. In all patients, after removal of the posterior hyaloid membrane, the blood located above the retina could be easily aspirated. In order to remove the remaining blood, the peeling of internal limiting membrane (ILM) was performed. No vital dyes were used, except for triamcinolone acetonide to assist posterior hyaloid membrane identification. Subsequently, an injection of $12.5 \mathrm{mg} / 0.1 \mathrm{ml}$ of recombinant tissue plasminogen activator (rtPA, Ophtalmos, São Paulo, Brazil) through a 41-gauge flexible microcannula (Synergetics ${ }^{\mathrm{TM}}$ ) was performed. The rtPA was gently injected to create a soft retinal detachment encompassing the entire blood clot. The injection was carefully located at the apex of the subretinal hemorrhage, avoiding the central macular area, near large retinal vessels. Great care was exercised so to avoid injecting air bubbles into the subretinal space. Finally, a fluid-air exchange was performed and dilute (20\%) sulfur hexafluoride $\left(\mathrm{SF}_{6}\right)$ gas was placed in the vitreous cavity. Patients were instructed to maintain a postoperative face down position during 5 consecutive days. In all cases the preretinal (subhyaloid), sub-IML and subretinal location of hemorrhage was confirmed during surgery. No argon laser photocoagulation was applied at the site of rtPA injection or at the macroaneurysm. Maneuvers such as manual extraction of clot, large retinotomy and infusion of liquid perfluorcarbon were not performed. No significant intra or postoperative complications were observed.

\section{RESULTS}

Four eyes of 4 patients ( 3 female) were studied. All patients complained of a sudden visual loss. Table 1 summarizes the clinical data. Age ranged from 63-78 years and all patients had a medical
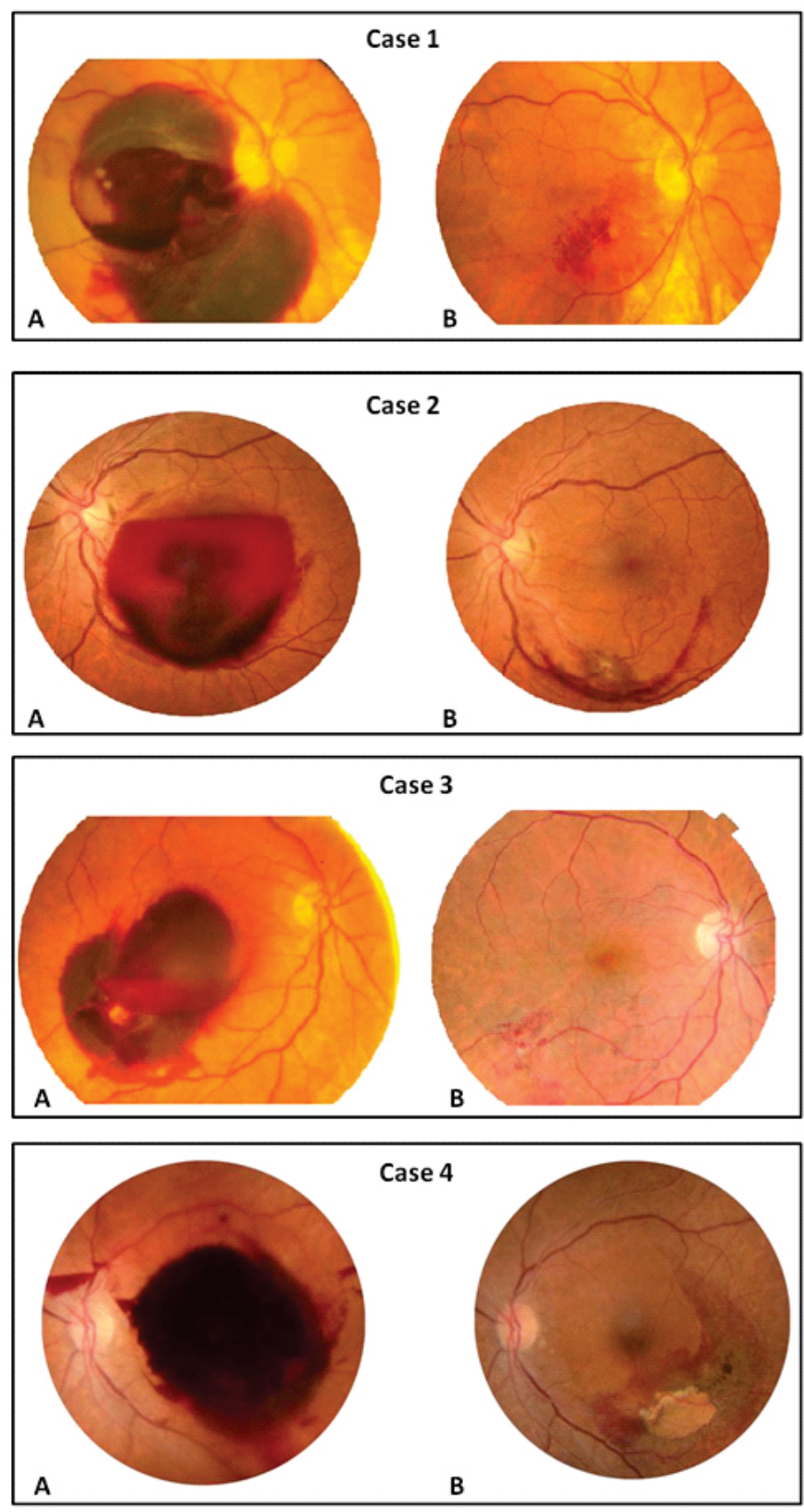

Figure 1: Four cases (rows 1 through 4) of massive submacular hemorrhage secondary to retinal artery macroaneurysm; A - the fundus photography in the first week; B - fundus image 4 weeks after surgery

Table 1

Clinical data of all 4 eyes with massive multilevel macular hemorrhage secondary to retinal arterial macroaneurysm treated with pars plana posterior vitrectomy associated with subretinal recombinant tissue plasminogen activator injection

\begin{tabular}{cccccccc}
\hline Patient no. & sex/age(y)/eye & Preoperative VA & Follow-up(months) & Final VA & Lens status & $\begin{array}{c}\text { Subfoveal } \\
\text { hemorrhage }\end{array}$ & $\begin{array}{c}\text { Duration of } \\
\text { hemorrhage (days) }\end{array}$ \\
\hline 1 & M/75/OD & HM & 17 & $20 / 80$ & pseudophakic & yes & 7 \\
2 & F/57/OS & CF 50cm & 10 & $20 / 30$ & pseudophakic & no & 3 \\
3 & F/81/OD & CF 50cm & 22 & $20 / 30$ & pseudophakic & no & 3 \\
4 & F/87/OS & CF 30cm & 13 & $20 / 60$ & pseudophakic & yes & 7 \\
\hline
\end{tabular}

M: male; F: female; OD:right eye; OS: left eye; y: years; VA: visual acuity; HM: hand motion; CF: count fingers 


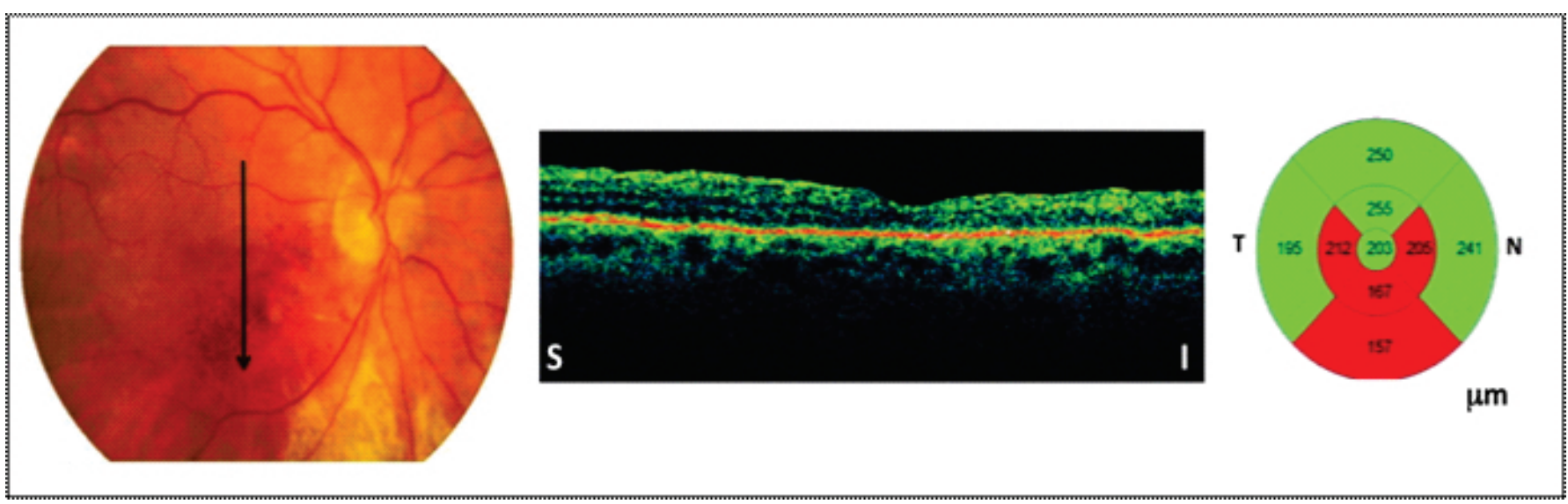

Figure 2: Case 1 - six weeks after posterior vitrectomy with subretinal rtPA injection, the subretinal blood in the macula was almost completely displaced and shifited inferiorly (fundus photograph on the left); OCT scan (in the middle) showed an indistinct external limiting membrane and disrupted IS/OS line and marked neurosensory retina thinning in nasal and temporal inner segments and inner and outer inferior segments (ETDRS map on the right); the final visual acuity was 20/80

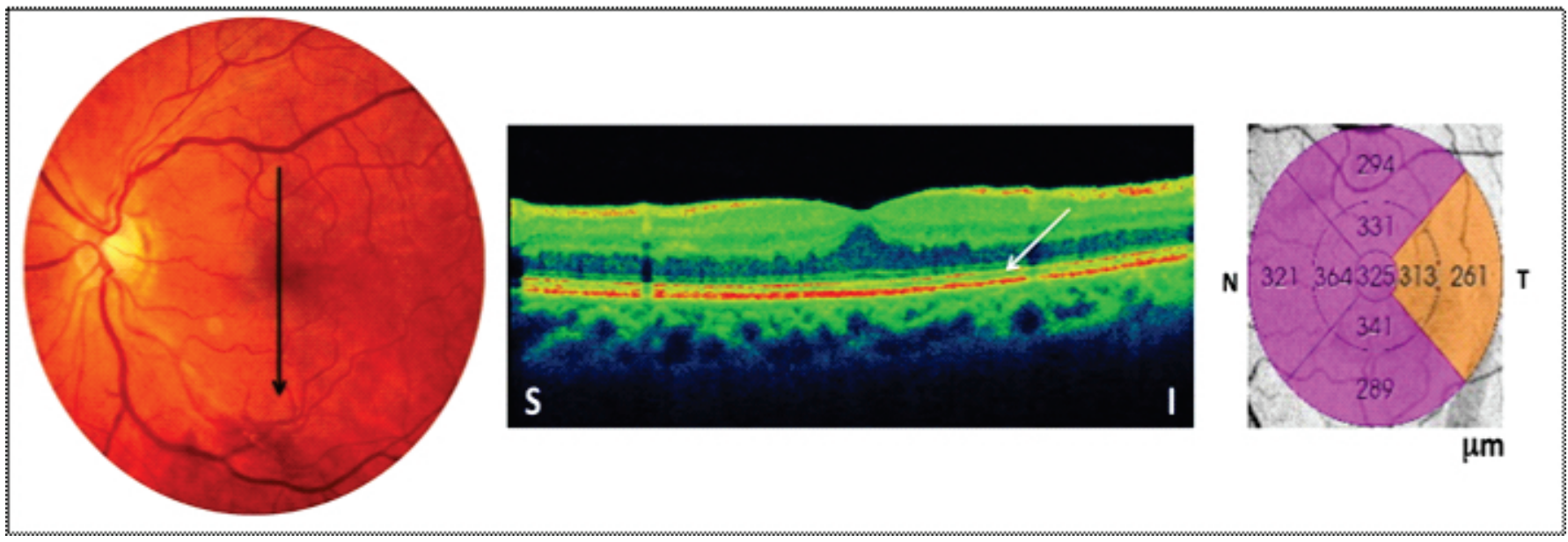

Figure 3: Case 2 - six weeks after treatment, the subretinal blood in the macula had been completely displaced and shifted inferiorly (left); OCT scan (middle) shows abrupt interruption of IS/OS line (white arrow) and a slight decrease of macular thickness (measurements) on the inner and outer temporal segments (ETDRS map on the right); the final visual acuity was 20/30

history of systemic arterial hypertension. None had history of Valsalva maneuver, use of anticoagulant or ocular disease, except for uncomplicated cataract surgery. One patient (case 2) was a heavy smoker.

The visual acuity of the affected eyes at presentation ranged from hand motions to count fingers at $50 \mathrm{~cm}$. The slit-lamp examination revealed posterior chamber IOL IN all eyes. Pupils and intraocular pressure measurements were unremarkable and all eyes showed extensive retinal hemorrhage involving more than two-thirds of macular area. In each case, macroaneurysm was located at the inferior temporal branch of the retinal artery (figure 1).

The time delay between the onset of symptoms and the surgery ranged from 3 to 7 days. After a mean follow-up of 15.5 \pm 5.19 months (range, 10-22 months), the postoperative visual acuity ranged from $20 / 30$ to $20 / 80$. All eyes demonstrated complete inferior displacement of the subretinal hemorrhage from the fovea within 10 days after the surgery (figure 1B). The mean time elapsed from surgery to complete reabsorption of subretinal hemorrhage from the macular area was 8 weeks (range, 6-10 weeks).
The OCT image demonstrated recovery of the foveal contour in all cases. In case 1, a massive subretinal hemorrhage beneath total macular area was visualized during vitrectomy. OCT sectional images after surgery showed marked neurosensory retina thinning in nasal and temporal inner segments and inner and outer inferior segments (on ETDRS map) with degenerated foveal structure, predominantly in its outer layers. The reflective line representing the junction between inner and outer segments of the photoreceptors (IS/OS line) beneath fovea was disrupted and almost complete absence of external limiting membrane (ELM) was observed (figure 2).

In case 2 , the hemorrhage was located lower and temporally to the fovea while there were no intraoperative signs of subretinal hemorrhage underneath the fovea. OCT performed after the surgical procedure demonstrated a slight decrease of macular thickness measurements on the inner and outer temporal segments and an abrupt interruption of IS/OS line (figure 3 ).

There was thicker subretinal hemorrhage in temporal inferior macular area and no blood beneath the fovea in case 3 . The OCT sectional images obtained after vitrectomy revealed mild irregularity in the contour of inner retina and irregularities 


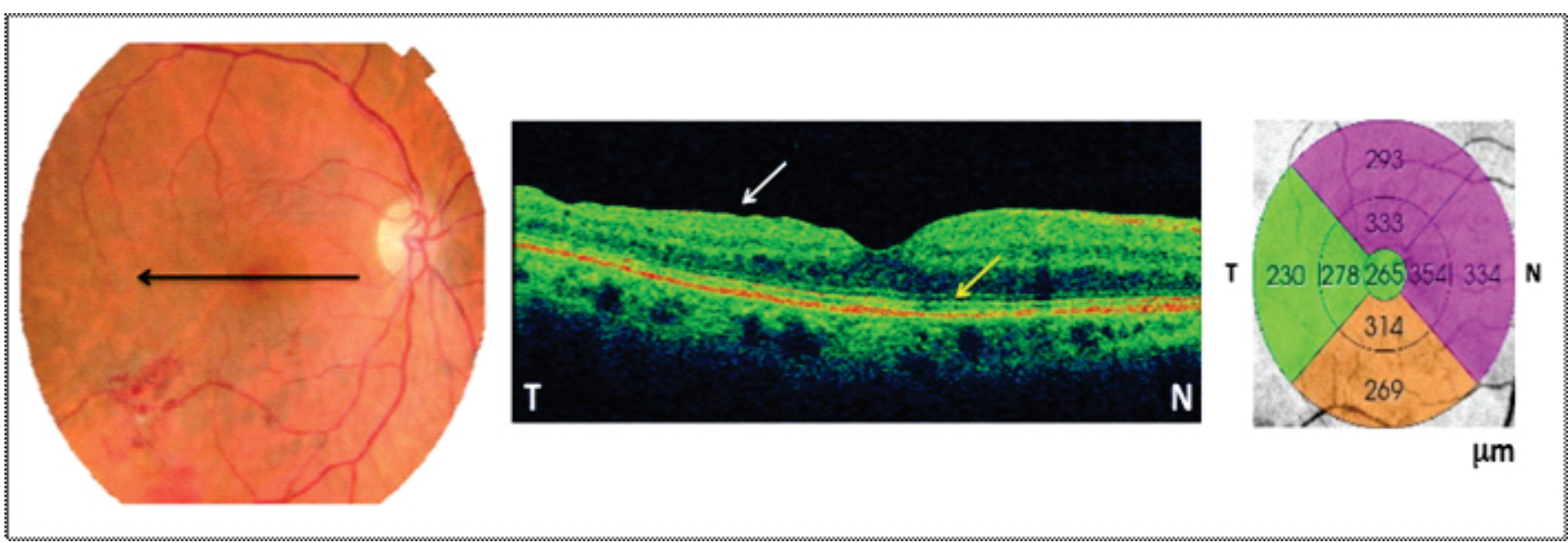

Figure 4: Case 3 - six weeks after treatment, the subretinal blood in the macula had been completely displaced and shifted inferiorly (left). OCT scan (middle) revealed an irregularity contour of inner retina (white arrow) and irregularities and discontinuity in reflective IS/OS line and ELM (yellow arrow). The final visual acuity was 20/30

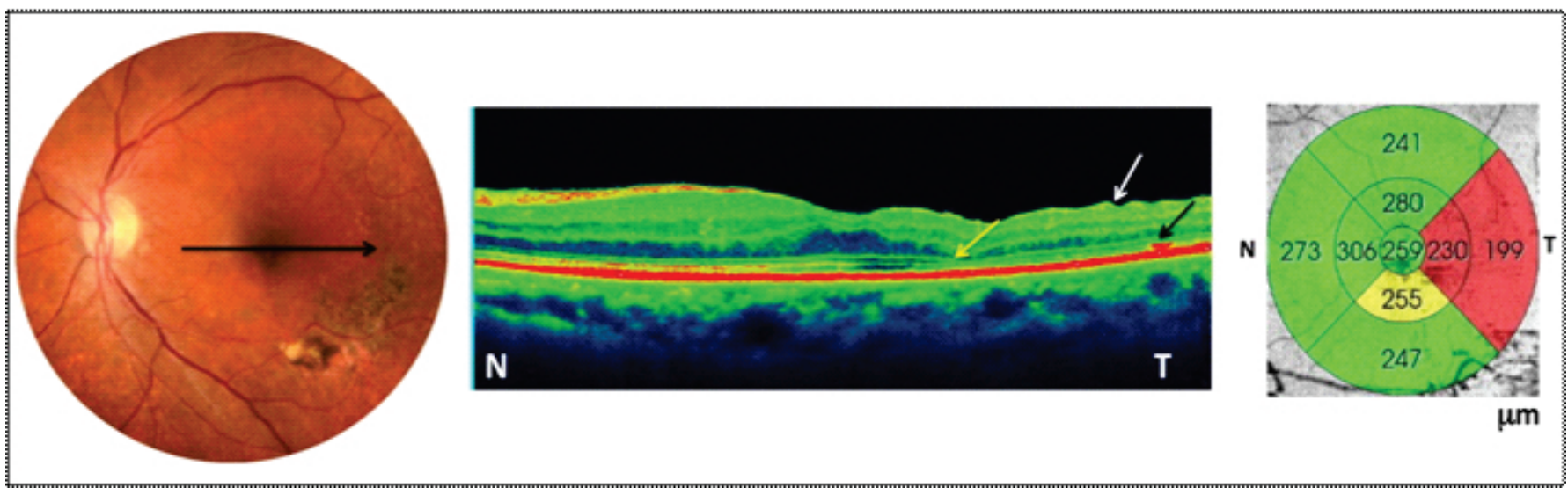

Figure 5: Case 4-six weeks after treatment no subretinal blood on the macula was (is) observed (fundus retinography on the left); OCT scan (in the middle) showed mild irregularity in the contour of inner retina (white arrow) and almost complete absence of IS/OS line beneath and temporally to the fovea (yellow arrow); a small hipereflective sign above the corresponding line of RPE (black arrow) was observed; the final visual acuity was $20 / 60$

and discontinuity in both IS/OS line and ELM (figure 4).

In case 4 , subretinal blood beneath the fovea was visualized during the surgery. OCT performed on follow up visits showed a moderate decrease of macular thickness measurements on the inner and outer temporal segments (ETDRS map). The OCT ultrastructural changes were: mild irregularity in the contour of inner retina and almost complete absence of IS/OS line beneath and temporally to THE fovea. A small hipereflective sign above the corresponding line of RPE was also observed (figure 5).

\section{DisCussion}

Visual outcome following SMH hemorrhage secondary to rupture of RAMA is variable but prognosis is particularly poor if untreated, especially when bleeding is massive ${ }^{(6,7,15)}$. While the best form of treatment is not established, many authors agree that the blood should be moved out of macular area. Basically, this can be achieved using pneumatic displacement, with or without vitrectomy. The use of rtPA to assist the mechanical displacement of submacular hemorrhage appears to be an effective adjuvant technique, since it promotes lysis of fibrin and liquefies the clot, facilitating pneumatic displacement of THE blood ${ }^{(22-23)}$. Hassan et al. investigated the efficacy and safety of treating thick SMH with intravitreous rtPA and pneumatic displacement ${ }^{(24)}$. Hemorrhages were secondary to age-related macular degeneration in 13 eyes and macroaneurysm and trauma in 1 eye each. In all eyes, the procedure resulted in complete displacement of thick submacular hemorrhage out of the foveal area. However, authors reported some serious complications such as breakthrough vitreous hemorrhage in three eyes and endophthalmitis in one. Four eyes developed recurrent hemorrhage 1 to 3 months after treatment, three of which were retreated with the same procedure. In more severe cases with the presence of massive submacular hemorrhage, this technique may present some limitations in mobilizing the clot and it is still controversial whether intra vitreous injection of rtPA is able to promote sufficient concentrations of this substance in subretinal space to promote clot lysis. The rtPA molecule exceeds the experimentally determined molecular exclusion limit of human retina ${ }^{(25)}$. Indeed, in the experiments of Kamei et al., rtPA injected into the vitreous of rabbits failed to pass through the intact reti$\mathrm{na}^{(26)}$. In addition, adequate interface between the gas bubble 
and submacular hemorrhage may not be achieved by attached or syneretic vitreous, which could adversely affect the pneumatic displacement of blood.

Modern ppV provides a means of removing sub-retinal hemorrhage and its usefulness to promote a complete displacement of submacular hemorrhage over pneumatic displacement was demonstrated in a recent study by Hillenkamp et al. ${ }^{(20)}$. The authors evaluated 47 eyes with SMH and compared the efficacy of $\mathrm{ppV}$ plus gas with intravitreal or subretinal injection of rtPA. They concluded that $\mathrm{ppV}$ with subretinal injection of rtPA plus intravitral gas was more effective than $\mathrm{ppV}$ with intravitreal injection of rtPA and gas in terms of complete displacement of SMH and functional improvement was observed in the majority of patients. Moreover, the direct retinal toxicity of subretinal rtPA injection was avoided. However, no OCT and electrophysiological tests were obtained in this study. In our cases, the complete displacement of SMH was achieved around the tenth day in all cases. In addition, no manual surgical extraction of the formed or liquefied clot was performed. These maneuvers may increase the risk of damage to the underlying RPE as well as to the photoreceptors and may be related to poor visual outcomes once the RPE cells and photoreceptors tend to be removed along with the clot due to their tight adherence to the hemorrhagic clot. Thereafter, large areas of RPE atrophy and retinal detachments resulting from the large retinotomy may occur in these $\operatorname{cases}^{(20,24,27)}$.

The four eyes cases reported in the present study had very poor visual acuity and massive SMH at presentation and showed great visual improvement after surgery. In a comparable study, in which 4 patients with acute $(\leq 7$ days $)$ multilevel $\mathrm{SMH}$ secondary to RAMA were treated with a similar technique (i.e. $\mathrm{ppV}$ associated with subretinal injection of rtPA), the authors also reported marked visual improvement with no significant complications, except mild nuclear sclerosis ${ }^{(27)}$. The final visual acuity ranged from $20 / 100$ to $20 / 30$ and OCT scans obtained at final visit showed a well-preserved foveal structure in all eyes ${ }^{(27)}$.

However, some questions should be addressed. In the present study as well as in the study by Sonmez et al. ${ }^{(27)}$, despite the significant visual improvement, a mild or moderate permanent visual loss remained in all eyes. Since our 4 cases were pseudophakic, the reason for this residual visual loss cannot be media opacity and OCT findings could be useful for better understanding the structural and functional relationships in these cases.

Abrupt rupture of RAMA often causes subretinal hemorrhage, that could be associated to sub-ILM and preretinal hemorrhage ${ }^{(4,12)}$. By penetrating the retina vertically, sudden massive bleeding from aneurysm can extend to all layers of the retina and to the subretinal space. Despite the early intervention, the presence of hemorrhage within retinal layers may lead to permanent visual loss by destruction of photoreceptor layer and impairment of metabolic exchanges. In fact, all cases presented signs of localized or diffuse macular thinning, suggesting a diffuse involvement of all retinal layers.

Previous studies have shown the importance of the IS/OS line as the hallmark of the integrity of the outer photoreceptor layer ${ }^{(28-30)}$. OCT reflections from the IS/OS are thought to arise from the abrupt change in the optical index of refraction at the boundary between the inner segments and the highly organized structure of the outer segments. Tsujikawa et al. reported that even after removal of subretinal hemorrhage beneath the fovea, significant damage to the integrity of the foveal photoreceptors layer was found and limited visual recovery was achieved. However, they did not mention the surgical procedure performed or the duration of $\mathrm{SMH}^{(21)}$. Large defects in the inner and outer segments of photoreceptors beneath the fovea may be responsible for poor visual acuity in such cases. In fact, in the present study, the two cases that presented with subfoeval hemorrhage and more severe visual loss (20/80 and 20/60), showed on OCT scans more pronounced IS/OS line disruption, suggesting that THE IS/ OS line integrity and the location of subretinal hemorrhage are vital for visual recovery.

Another reasonable explanation for these structural findings may lie in the toxic action of rtPA into the subretinal space. Some experimental and clinical studies showed the toxicity of high dosage $(>50 \mu \mathrm{g})$ of intravitreal rtPA to the retina,WHILE others have shown good tolerability at lower concentration ${ }^{(27,31,32)}$. Although we used a dosage considered to be safe $(12,5 \mu \mathrm{g})$, we cannot assume that there was no toxic effect induced by rtPA in the subretinal space. Some complications related to $\mathrm{ppV}$ associated with subretinal injection of rtPA, such as retinal detachment, retinal break, vitreous hemorrhage, macular epiretinal membrane, macular hole and cataract have been previously reported. Nevertheles, no serious complications occurred during our follow-up period.

The current study was primarily limited by its retrospective nature and also by small number of patients studied together with the lack of standardized follow-up visits. Based on our findings we conclude that the pars plana posterior vitrectomy associated with subretinal rtPA injection with intravitreal gas seems to be a safe and effective technique to promote visual improvement in patients with multilevel macular hemorrhage secondary to retinal arterial macroaneurysm. The OCT findings showed that despite the great functional improvement, the presence of submacular blood, especially in cases with subfoveal involvement, promotes a permanent structural damage to the neurosensory retina, especially in outer photoreceptors layers, which may explain, at least in part, the presence of permanent visual function impairment in such cases.

\section{ReFERENCES}

1. Bopp S. [Subretinal hemorrhage. Natural course and staging]. Ophthalmologe, 2012. 109(7): 635-43. German.

2. Avery RL, Fekrat S, Hawkins BS, Bressler NM. Natural history of subfoveal subretinal hemorrhage in age-related macular degeneration. Retina. 1996;16(3):183-9.

3. Robertson D M, Macroaneurysms of the retinal arteries. Trans Am Acad Ophthalmol Otolaryngol. 1973. 77(1): OPP55-67.

4. Rabb MF, Gagliano DA, Teske MP. Retinal arterial macroaneurysms. Surv Ophthalmol. 1988;33(2):73-96. Review.

5. Lavin MJ, Marsh RJ, Peart S, Rehman A. Retinal arterial macroaneurysms: a retrospective study of 40 patients. Br J Ophthalmol. 1987;71(11):817-25.

6. Bennett SR, Folk JC, Blodi CF, Klugman M. Factors prognostic of visual outcome in patients with subretinal hemorrhage. Am J Ophthalmol 1990;109(1):33-7.

7. Berrocal MH,Lewis ML, Flynn HW Jr. Variations in the clinical course of submacular hemorrhage. Am J Ophthalmol. 1996;122(4):486-93. Erratum in: Am J Ophthalmol 1996;122(6):920.

8. Glatt H, Machemer R. Experimental subretinal hemorrhage in rabbits. Am J Ophthalmol. 1982; 94(6):762-73.

9. Brown DM, Sobol WM, Folk JC, Weingeist TA. Retinal arteriolar macroaneurysms: long-term visual outcome. Br J Ophthalmol. 1994;78(7):534-8. 
10. Godel V, Blumenthal M, Regenbogen L. Arterial macroaneurysm of the retina. Ophthalmologica. 1977;175(3):125-9.

11. Joondeph BC, Joondeph HC, Blair NP. Retinal macroaneurysms treated with the yellow dye laser. Retina. 1989; 9(3):187-92.

12. Panton RW, Goldberg MF, Farber MD. Retinal arterial macroaneurysms: risk factors and natural history. $\mathrm{Br} \mathrm{J}$ Ophthalmol. 1990; 74(10):595-600.

13. Humayun M, Lewis H, Flynn HW Jr, Sternberg P Jr, Blumenkranz MS. Management of submacular hemorrhage associated with retinal arterial macroaneurysms. Am J Ophthalmol. 1998;126(3):358-61.

14. Gastaud P, Rouhette H, Fillacier K, Nègre F. [Role of vitrectomy in the treatment of retinal arterial macroaneurysms]. J Fr Ophtalmol. 1999;22(6):639-44. French.

15. McCabe CM, Flynn HW Jr, McLean WC, Brod RD, McDonald HR, Johnson MW, Williams GA, Mieler WF. Nonsurgical management of macular hemorrhage secondary to retinal artery macroaneurysms. Arch Ophthalmol. 2000;118(6):780-5.

16. Mizutani T, Yasukawa T, Ito Y, Takase A, Hirano Y, Yoshida M, Ogura Y. Pneumatic displacement of submacular hemorrhage with or without tissue plasminogen activator. Graefes Arch Clin Exp Ophthalmol. 2011;249(8):1153-7.

17. Johnson MW. Pneumatic displacement of submacular hemorrhage. Curr Opin Ophthalmol. 2000;11(3):201-6. Review.

18. Haupert CL, McCuen BW 2nd, Jaffe GJ, Steuer ER, Cox TA, Toth CA, Fekrat S, Postel EA. Pars plana vitrectomy, subretinal injection of tissue plasminogen activator, and fluid-gas exchange for displacement of thick submacular hemorrhage in age-related macular degeneration. Am J Ophthalmol. 2001;131(2):208-15

19. Olivier S, Chow DR, Packo KH, MacCumber MW,Awh CC. Subretinal recombinant tissue plasminogen activator injection and pneumatic displacement of thick submacular hemorrhage in Age-Related macular degeneration. Ophthalmology. 2004 Jun;111(6):1201-8. Erratum in: Ophthalmology. 2004;111(9):1640.

20. Hillenkamp J, Surguch V, Framme C, Gabel VP, Sachs HG. Management of submacular hemorrhage with intravitreal versus subretinal injection of recombinant tissue plasminogen activator. Graefes Arch Clin Exp Ophthalmol. 2010;248(1):5-11.

21. Tsujikawa A, Sakamoto A, Ota M, Oh H, Miyamoto K, Kita M, Yoshimura N. Retinal structural changes associated with retinal arterial macroaneurysm examined with optical coherence tomography. Retina. 2009 Jun;29(6):782-92.

22. Lewis H. Intraoperative fibrinolysis of submacular hemorrhage with tissue plasminogen activator and surgical drainage. Am J Ophthalmol. 1994;118(5):559-68.
23. Peyman GA, Nelson NC Jr,Alturki W, Blinder KJ,Paris CL, Desai UR, Harper CA 3rd.Tissue plasminogen activating factor assisted removal of subretinal hemorrhage. Ophthalmic Surg. 1991;22(10):575-82.

24. Hassan AS, Johnson MW, Schneiderman TE, Regillo CD, Tornambe PE, Poliner LS, Blodi BA, Elner SG. Management of submacular hemorrhage with intravitreous tissue plasminogen activator injection and pneumatic displacement. Ophthalmology. 1999;106(10):1900-6; discussion 1906-7.

25. Jackson TL, Antcliff RJ, Hillenkamp J, Marshall J. Human retinal molecular weight exclusion limit and estimate of species variation. Invest Ophthalmol Vis Sci. 2003;44(5):2141-6.

26. Kamei M, Misono K, Lewis H.A study of the ability of tissue plasminogen activator to diffuse into the subretinal space after intravitreal injection in rabbits. Am J Ophthalmol. 1999;128(6):739-46.

27. Sonmez K, Ozturk F, Ozcan PY.Treatment of multilevel macular hemorrhage secondary to retinal arterial macroaneurysm with submacular tissue plasminogen activator. Eur J Ophthalmol. 2012;22(6):1026-1031.

28. Sano M, Shimoda Y, Hashimoto H, Kishi S. Restored photoreceptor outer segment and visual recovery after macular hole closure. Am J Ophthalmol. 2009;147(2):313-318.e1.

29. Chang LK, Koizumi H, Spaide RF. Disruption of the photoreceptor inner segment-outer segment junction in eyes with macular holes. Retina. 2008;28(7):969-75.

30. KoTH,Fujimoto JG, Schuman JS, Paunescu LA, Kowalevicz AM, Hartl I, Drexler W, Wollstein G, Ishikawa H, Duker JS. Comparison of ultrahigh- and standard-resolution optical coherence tomography for imaging macular pathology. Ophthalmology. 2005;112(11):1922.e1-15.

31. Johnson MW, Olsen KR, Hernandez E. Tissue plasminogen activator treatment of experimental subretinal hemorrhage. Retina. 1991;11(2):250-8.

32. Chen CY, Hooper C, Chiu D, Chamberlain M, Karia N, Heriot WJ. Management of submacular hemorrhage with intravitreal injection of tissue plasminogen activator and expansile gas. Retina. 2007;27(3):321-8.

\section{Corresponding author:}

Leonardo Provetti Cunha

Av. Barão Rio Branco, nº 4051 - Bairro Bom Pastor

Juiz de Fora (MG), Brasil

Zip code: 36021-630

E-mail: leonardo_provetti@yahoo.com.br 